\title{
Three Ideas of the University
}

\author{
James Alexander \\ Department of Political Science, Bilkent University, Bilkent, Ankara 06800, Turkey
}

\begin{abstract}
What is a university? In the nineteenth century John Henry Newman famously spoke of "the idea of a university." This phrase has dominated all discussions of the nature of the university since. Most contemporary writers are against any attempt to theorise the university in terms of a single idea. But against the now standard view that universities should only be characterised empirically as institutions that perform many different activities, I attempt to defend the idea of the university, not by reviving a single idea of the university but by suggesting that there are, at root, three ideas of the university. These are rival ideas, and strictly incommensurable, though they often exist together in a state of tension in actual universities. I call them the eternal, the immortal, and the immediate ideas of the university.
\end{abstract}

\section{KEYWORDS}

Universities; Education; Idea; History; Philosophy

Today it is no longer possible to define a university in terms of a single idea.

—Noel Annan, The Dons, p. 56

\section{Introduction}

The university is now more significant than it has ever been: much has been written about it in relation to its practical status, and there has also been a fair amount of historical study. But in recent years there has not been much philosophical consideration of the university: of what a university is. There was some attempt at a sketch of a philosophical idea of the university in the nineteenth century, most famously in John Henry Newman's lectures, eventually published in 1852 under the title The Idea of a University. Many writers still refer back to Newman's conception, but usually they have practical matters on their mind, and so dismiss the attempt to define an "idea" of the university: indeed, they consign it to history by saying that such definitions are no longer possible. In this essay, I attempt something philosophical along the lines laid down by Newman, though I shall not sketch one idea of the university, but three ideas. For reasons that will become clearer further on, I shall call them the eternal, the immortal, and the immediate ideas of the university.

What is an idea? We sometimes mean by it merely an opinion or a view. But this is not what Newman meant by an idea. He took it from Coleridge, who wrote: 
By an idea, I mean (in this instance) that conception of a thing, which is not abstracted from any particular state, form or mode, in which the thing may happen to exist at this or that time; nor yet generalised from any number or succession of such forms or modes; but which is given by the knowledge of its ultimate aim. ${ }^{1}$

Behind Coleridge there was Kant, who had written: "An Idea is nothing other than a concept of perfection which is not yet found in experience." ${ }^{2}$ And after Kant, of course, there was William von Humboldt, with his original "Idee der Universität," famous as the model for the University of Berlin (founded in 1810) and many universities afterwards.

An idea of the university is not a view of a university held at this or that time; nor is it a generalisation from several views. It is a simplification, not a diminishing simplification, but an exalting simplification: an attempt to express in simple terms a concept of the perfection of the university. "The idea of the idea of a university," as historian Sheldon Rothblatt has called it, is a beguiling one, and Newman was responsible for popularising it in English. It can now seem a distinctively nineteenth-century idea, and therefore out of date. Rothblatt's own view is that "a single idea of the university has never truly existed." ${ }^{3}$ This may be so. But whereas he would probably emphasise the word idea in this sentence, I would instead emphasise single. No single idea of the university has ever existed.

In this article I begin with Newman rather than Humboldt because Newman's contradictions are richer than Humboldt's. ${ }^{4}$ Newman's lectures, originally delivered in May 1852 as "University Teaching Considered in Nine Discourses," were published in the same year as Discourses on the Scope and Nature of University Education, republished in 1859 with some changes as The Scope and Nature of University Education and finally published again in 1873, along with other essays and lectures, as The Idea of a University. ${ }^{5}$ Newman's final title has had far more influence than his argument. In the last century or so a remarkable set of figures including Karl Jaspers, F. R. Leavis, Michael Oakeshott, Kenneth Minogue, J. M. Cameron, A. L. Halsey, Jaroslav Pelikan, Roger Scruton, and Duke Maskell and lan Robinson have written about some variant of "the idea of a university," though few of them have used Newman's argument as a starting point. ${ }^{6}$

What was Newman's idea of the university? The answer is far from simple. Owen Chadwick commented that Newman's lectures "are easy to misunderstand, and on occasion contradict themselves."7 Joseph Dunne notes the irony "that while Newman's name lives on because the Idea has achieved classic status in the context of debates about the nature and purposes of universities, its place in these debates is now almost entirely ceremonial." ${ }^{8}$ And Maskell and Robinson judge that, taken as a whole, his Idea of a University "isn't a coherent piece of work":

There's a lot that's slack in it, and it suffers badly from equivocation. The trouble is that Newman wants to defend liberal education not just to his own satisfaction and on his own terms but also to the satisfaction and on the terms of his opponents, who want education to be above all else practically useful. ${ }^{9}$

More specifically: "Newman tries to justify, to a professional and practically-minded people, an education without any obvious professional or practical purpose, on the grounds that it's the best education, from a professional and practical point of view." ${ }^{10}$ Many writers, who are more interested in Newman's title than his arguments, fail to notice the confusion in his position. While Maskell and Robinson argue that Newman was torn between two ideas of the 
university, I would go even further and say that there are not just two ideas of the university in Newman's book—the "liberal" and the "useful"—but also a third idea, a "religious" idea. Perhaps this should come as no surprise, given that Newman was an influential Catholic thinker and eventual Cardinal.

Throughout his lectures Newman explicitly speaks of "religious knowledge," "liberal knowledge," and "useful knowledge." The end of liberal education is not the acquirement of knowledge for use but for the enjoyment of knowledge itself: which means that knowledge is not an instrument for some other end but an end in itself-and therefore strictly useless. The acquirement of useful knowledge occurs through "instruction" whereas the acquirement of knowledge for its own sake occurs through "education." "Education is a higher word; it implies an action upon our mental nature, and the formation of a character." Liberal knowledge is "knowledge worth possessing for what it is, and not merely for what it does." But the other sort of knowledge, religious knowledge, as Newman makes clear over several pages of the sixth discourse, is concerned not merely with knowledge as an end in itself but with knowledge as a means to a further end. Liberal education is "no guarantee for sanctity or even for conscientiousness": it is only a guarantee of "intellectual excellence." Only religious knowledge is concerned with sanctity; only it can guarantee the unity of thought central to the idea of the university. In the tenth discourse we again encounter this threefold characterisation: "Useful knowledge is the possession of the truth as powerful, Liberal knowledge is the apprehension of it as beautiful..11 But these two, taken alone, cannot focus the mind, and so Newman turns to "Revealed Religion" and the "Theological Truth" that render all other sorts of truth merely relative. Without ever admitting it, Newman does not advocate one idea but three incommensurable ideas of the university.

You may well suppose that my terms for these three-eternal, immortal, and immediate-are overly refined, perhaps irrelevant, or confusing. But I choose them in preference to Newman's terms "religious," "liberal" and "useful" because they clearly identify the ideas I think are fundamental. (The word "liberal" is especially ambiguous.) The advantage of these terms over Newman's, or those of any other writer, are, firstly, that they are abstract and as such fit to express ideas, and, secondly, that they indicate the contrast in attitude exemplified by each idea, thus enabling them to be seen in some sort of sequence or system:

(1) What the eternal university seeks is stasis, completion, tranquility, or thankfulness: a worshipful or meditative mentality, a retreat from crisis, disappointment, suffering, desire, striving and death. Its vision is one in which the world is studied in order that it can be turned away from, and the particular understandings of mankind recognised as incomplete and unworthy.

(2) What the immortal university seeks is continuity, tradition, glory, or genius, their preservation and the growth of knowledge: a conveyance of successively charismatic or increasingly accurate visions across the ages, suggesting that we can outlive our own time by teaching through the generations. Its vision is one in which the world is studied in order that the understandings of mankind may be recognised and shared as some of our worthiest achievements. 
(3) What the immediate university seeks is utility, practicality, or relevance: a training for engineers, lawyers and medics, and an institution for research into the ways that the problems of society may be dealt with. Its vision is one in which the world is studied in order to master or maintain it, as far as possible, and manage the small matter of our survival in it.

Most writers who have written about the university since the expansion of university education in the mid-twentieth century-from Leavis, Oakeshott, and Bloom right through to Ginsberg, Nussbaum and Collini-have been humanists who have contrasted the third with the second idea of the university. ${ }^{12}$ They have supposed, sometimes defiantly, sometimes hesitantly, that the second idea of the university is the idea of the university, and that the third is not an idea at all. Or they say that the third is the reality that explains why the second fails. They are wrong. The third is an idea. But as Newman and others like Alasdair Maclntyre and Mike Higton have claimed, so is the first. ${ }^{13}$ All three ideas are necessary elements in any adequate conception of the university as we encounter it. They are contradictory, even incommensurable, but necessary. Without any one of them, we would have something else: a mere seminary, or an arbitrary assemblage of separate sciences united only by existing within the same institution, or a school of vocational training along with researches in engineering, medicine and law. Perhaps these are what we do have, and are likely to have, in the future. But I would argue that the three ideas characterised in this article will be present as long as we continue to use the prestigious term "university."

Let me characterise each idea in turn.

\section{The Eternal University}

The eternal university has four characteristics. Firstly, it is orientated towards what is not of this world. That is to say, it looks beyond the material, the animal and the human to something higher, something divine, some truth or peace that is beyond the confusion and suffering evident in the world. Secondly, it therefore has a unity of concern: it is concerned with what is universally true, and seeks to understand all things in relation to a unity of consciousness. This means that all separate forms of study are secondary to an absolute understanding, or absolute absence of understanding, that always has cognitive priority. Thirdly, it means that study is neither study for its own sake nor study for the sake of achieving some particular end, but is study for the sake of the end of all ends: study that takes the form of worship or meditation or thankfulness. It is not concerned with glory or beauty or benefit, except the highest benefit which follows when the student puts him or herself in relation to the truth of the universe, which has priority over all individual aspiration. Fourthly, it is in some sense an institution acting on behalf of all human society, but because it is concerned with ultimate truth, beyond the mere truths of this world, it can only actively be carried out by a certain class of that society, an elite of clerics.

Most of the great schools of antiquity and thereafter were as much religious as secular, and for a long time rather more religious than secular in orientation. Christopher Beckwith notes that the Buddhist vihara in India and Central Asia taught theology and law, or what Buddhists called dharma. ${ }^{14}$ George Makdisi notes that in the Islamic madrasa, "education was directed towards religious ends: the salvation and 
eternal happiness of men and the glory of God." ${ }^{15}$ The same was true of the Christian descendant of the vihara and madrasa, the college, and true of the related but apparently wholly original legal institution, the medieval European "university" (which was originally the name for a body of scholars who incorporated themselves into a universitas). "The medieval university gave institutional expression to the medieval belief in higher and lower degrees of knowledge," the historian Gordon Leff tells us. "Only the understanding contained in God's word represented pure, absolute truth." Although medieval universities are not to be identified with the eternal university, the idea shone through them. Leff notes that they "put the search for truth in any full or absolute sense beyond the scope of all human enquiry." ${ }^{16}$ The eternal idea assumes, as Simone Weil put it, that "a science which does not bring us near to God is worthless." ${ }^{17}$ And it assumes, as J. P. Berkey puts it, that "in a very real sense, learning is worship." ${ }^{18}$

The eternal university depends on a distinction between this world and a reality which is not of this world: between heaven and earth, between the city of God and the city of earth, between nirvana and samsara. So, for instance, Kenneth Minogue observes that in Europe "the universities were the beneficiaries of the persistent dualism of medieval Christian thought." He quotes Hugh of St Victor as saying that study was both a meditation on death and an investigation of human and divine causes. And yet Minogue, in typical modern fashion, is so committed to the immortal idea of the university that he cannot admit that any other idea of the university is an idea worthy of the name: "There comes a point when the academic and religious roads must diverge: academic inquiry will begin to press on and to destroy what religion finds it salutary to take for granted." So for Minogue, as for others, worship and study are only "tangentially related." ${ }^{19}$ But this is not so for anyone who recognises the eternal idea of the university. Academics, Stoics, Buddhists, Muslims, and Christians all had such an idea. All of them thought that knowledge-for-its-own-sake should be subjugated for the good of the world to a higher and unified truth.

"One of Dr Johnson's more magisterial errors," according to F. S. L. Lyons, was to say that "a university (studium generale) was a place of universal learning." ${ }^{20}$ But if this is a magisterial error, it is one frequently made. Here is Newman: "That a university was really, in its idea, the seat of all learning is plain from its very name: in saying which I am not taking any stand upon the derivation of the word, but upon its recognised meaning, however it came to mean it." ${ }^{21}$ Everything written about the university, even by those who try to emphasise its actual plurality, is written in the shadow of the eternal idea of the university. Plato's philosophia and even Herodotus's historia (now called "research") are not ends in themselves but only means to a further end. That end is something entirely different from the acquisitiveness associated with the pursuit of knowledge. It is more like a relinquishment of attainment through gratitude or equanimity in the face of truth. As G. K. Chesterton put it, "thanks are the highest form of thought." ${ }^{22}$ And this is an idea that has never been wholly lost. It was there in Newman, and it is there in Maclntyre, who in a recent book on the subject approvingly quotes Newman's claim that the sciences in the modern university are "partial views or abstractions." Unity can only come from faith. "Reason without Christian faith is always reason informed by some other faith, characteristically an unacknowledged faith." Maclntyre is willing to admit that the modern research university has had three successes. The first is in the many discoveries and advances of the separate or "partial" sciences. The second is in setting 
itself up to instruct students in the resources and skills that are "needed in an advanced capitalist society" by way of "specialisation and professionalism." Both of these mean the university has become a "ragbag of disciplines and subdisciplines," "each pursued and taught in relative independence of all the others" (i.e., Newman's "bazaar"). The third is that universities "in the early twenty-first century are wonderfully successful business corporations subsidised by tax exemptions and exhibiting all the acquisitive ambitions of such corporations." As we shall see, this criticism of the immediate idea of the university is common amongst exponents of the immortal idea of the university. But part of Maclntyre's argument is that the immortal idea makes no sense without the eternal idea: "Any Catholic university in which such projects were to be successfully pursued would need to have structures and goals very different from those of the great secular research universities, and not just by reason of the central place given to the study of theology." 23

The eternal idea of the university still casts a shadow over actual universities. Even if we supposed that it was unlikely that a fully confessional or theological university could ever be established, the idea of the eternal university would live on in the sense that a university should form a unity of endeavour and should offer an understanding that transcends its actual practices. Here it is only an etymological, not a philosophical, mistake, to associate the university with universality. In the middle of the twentieth century Robert Maynard Hutchins wrote that modern "universities, instead of leading us through the chaos of the modern world, mirror its confusion" because they have "no ordering principle." Yet what did he mean by an "ordering principle"? Something found in something higher than study itself: "Without theology or metaphysics a unified university cannot exist." In saying this he was making the characteristic claim of someone who believes in the eternal idea of the university. ${ }^{24}$

It is now necessary to consider the second and by far the most famous idea of the university, the immortal idea.

\section{The Immortal University}

The immortal university, like the eternal university, has four characteristics. Firstly, it is concerned with knowledge for its own sake, and so has a willingness to follow the path of study wherever it leads. Secondly, and consequently, there is a fundamental ambiguity about whether the forms of study, the separate sciences, are part of a united endeavour or not. Thirdly, since knowledge is limited by what the human mind is capable of understanding, it is concerned with preserving older fragments of knowledge in order to initiate the uninitiated into this knowledge, not for the sake of dogmatic repetition, but for the sake of criticism and continuation of a tradition. Education is here an initiation into a civilisation. We could even say it is an initiation into the canons of that civilisation rather than into truth as such. According to this idea there is no one truth, revelation or doctrine. Instead there are "great books," established methods, and a succession of conjectures and refutations that can be ordered into paradigms. Fourthly, this idea, in eschewing purpose, in trying to separate its activities from church and state, risks seeming decadent, wasteful, self-indulgent, a sign of a society so much in surplus that it can decorate itself with garlands of knowledge. Here there is often an emphasis on the genius of the thinker, the insight of the researcher, and the charisma of 
the teacher, who is therefore named and remembered-whether he be Hegel, Newton, or Aquinas. This university is necessarily elitist, though the elite is not an elite of clerics but an elite of what we could call, adjusting Coleridge's definition, a clerisy.

This idea of the university is humanist. In Leavis's words, "It is the preoccupation with cultural values as human and separable from any particular religious frame or basis, the offer of a cultural regeneration that is not to proceed by way of a religious revival, that prompts the description 'humanist'."25 Humanism depends on a lowering of the status of religion. It arose in the Renaissance, when scholars looked back to the classics instead of scripture. In all its guises, humanism, according to Emil Brunner, "gives man a place over, against and somehow outside of nature and elevates him above it." He thought it was "certainly one of the grandest and most beautiful achievements of the human mind." "Although it was the life programme of a small elite, and although it was so ambitious that it could be shared only by men of high culture, it has exerted a great influence." ${ }^{26}$ During the Enlightenment, humanist studies were extended to include the natural sciences. These sciences were a logical corollary of humanism, for setting the humanist outside nature and elevating him above it made it possible for the humanist to study nature objectively as well as culture subjectively. The newly separated forms of study exposed the paradox of the study of man in nature by the same man outside nature. But paradoxes could be tolerated, since each science had a limited method and conditions of understanding appropriate to its subject matter. The consequence was the loss of any authoritative central control of all knowledge. From now on, as Minogue puts it, "academic life [was] always, and rightly, conceived of as a discussion in which there cannot in any circumstances be a final voice." 27

The immortal idea is often criticised for being the concern of an elite. Anthony Grafton and Lisa Jardine are caustic about its legacy: "Western Europe as a whole (and North America) became involved in the mystification of arts education-a connivance in overlooking the evident mismatch between ideals and practice-which has clouded our intellectual judgement of the progress and importance of the liberal arts from the days of Guarino [de Varona] down to T.S. Eliot, Leavis and the twentieth-century guardians of European 'civilisation'." 28 It was when the humanist tradition was roundly criticised in this way in the twentieth century that the immortal idea of the university was characterised in full. Noel Annan commented that Michael Oakeshott's "was the finest evocation of the 'the idea of the university' since Newman's; and more subtle and persuasive." ${ }^{29}$ At root it was fairly simple. Oakeshott distinguished "vocational" education from "university" education. He suggested that the former has no place in the university, which should not "reflect the world." "The contemporary world offers no desirable model for a university." This is because the university is not about utility. Properly understood, it is an "interval" in which we can achieve what Keats called "negative capability." Oakeshott thought that any other idea of the university was not an idea of the university but a justification for its dissolution. About those who advocate the expansion of the universities, he wrote: "Their aim is loot-to appropriate to themselves the organisation, the shell of the institution, and convert it to their own purposes. The problem of the universities today is how to avoid destruction at the hands of men who have no use for their characteristic virtues, men who are convinced only that 'knowledge is power'." They "belong to a world of power and utility, of exploitation, 
of social and individual egoism, and of activity, whose meaning lies outside itself in some trivial result or achievement-and this is not the world to which a university belongs." 30

If the immortal university excludes vocational study, it is because it is concerned not with immediate problems but with those of longer duration. Consider Stefan Collini's mot about the modern suggestion that scholars should engage in collaboration: "We do collaborate all the time, of course; it's just that most of our collaborators are dead." ${ }^{31}$ Leavis used phrases such as "cultural continuity," "continuous collaborative renewal," "continuous collaborative creativity," and "complex collaborative community." ${ }^{32}$ Oakeshott was responsible for the saying that a university is an "initiation into a civilisation." By "civilisation" he meant a conversation between different branches of knowledge where the relationships between them are "not those of assertion and denial but the conversational relationships of acknowledgement and accommodation. ${ }^{\prime 33}$ Leavis's slightly more intensified conception was that it concerns not conversation but "criticism." The university is an institution of "liberal education." Its purpose is "to explore the means of bringing the various kinds of specialist knowledge and training into effective relation with informed general intelligence, humane action, social conscience and political will." This is, of course, an argument for unity of a sort: to "bring the special sciences and studies into the significant relation" which Leavis thought could only be done in a "school of humanities." ${ }^{34}$ Oakeshott was rather more pessimistic about where unity was to be found, if anywhere: "Its centre of gravity [has] moved from the culture of antiquity but without any firm settlement elsewhere." ${ }^{35}$ But Leavis insisted that "the presence of the diverse studies together, not without significant reciprocal influence, is necessary if the university is to be the centre of consciousness for the community it ought to be." ${ }^{36}$ If Leavis found the centre in the study of literature, Allan Bloom found it in philosophy: "Philosophy, not history or anthropology, is the most important human science." ${ }^{37}$ So did Minogue: "Philosophy has always been recognised as a paradigm of academic enquiry." ${ }^{38}$ Edward Shils struck a more realistic note:

\footnotetext{
At one time, the humanistic disciplines, the 'art and sciences' or the 'philosophical faculty' were the centre of the university.... Humanistic departments or faculty represented to their colleagues what a university ought to be.... There are in the late twentieth century some very distinguished scholars in the humanities, but they are just not in the ascendancy; they are living on the defensive, surrounded by very alien spirits. These alien spirits are at present in a self-indulgent delirium of destructiveness. They have broken with the traditions from which they have come and what they have to put in its place are things of only very small value. $^{39}$
}

The defence of the immortal university is complicated, since it has to conceive the university as existing in relation to the society whose civilisation it seeks to preserve, while nonetheless being set apart from that society, especially in the matter of creating an elite. Bloom argued that the university "must resist the temptation to try to do everything for society." It needs "rare individuals." ${ }^{40}$ Leavis agreed: "Schools and colleges are not something apart from the social order to which they belong." Yet "education should be in some ways concerned with countering certain characteristic tendencies of civilisation." And, he added: the university is "not merely a place of learning, research 
and instruction, but itself a nucleus (one of a number) of the greater public, the spiritual community the country needs." 41

The idea of the immortal university has become much clearer as a consequence of the erosion of the idea of the eternal university. The immortal university is not subordinated to an absolutely high revealed truth, but involves a search for reasoned truths, where the search for those truths is to achieve a theoretical apprehension of what can be known about the universe. Here study is, strictly, useless: shorn of all purpose or use. In this university the "arts" and "sciences" are separated from confession or worship, and also from the vocations. In this liberation of study, there is thus a division into subjects, into what Newman called "literature" and "science", and what we now call the humanities and the sciences. The humanities are especially concerned with "civilisation," "canons," and "criticism," while the sciences are concerned with rationality, generalisation and quantification. As Newman explained: "These various partial views or abstractions, by means of which the mind looks out upon its object, are called sciences." "They arrange and classify facts; they bring separate phenomena under a common law; they trace effects to a cause." "Viewed all together, they become the nearest approximation to a representation or subjective reflexion of the objective truth, possible to the human mind. ${ }^{42}$ But they lack unity (and hence are not of the eternal university); and they lack obvious use (and hence are not of the immediate university). The sciences were not pursued because they were useful until, at the earliest, the nineteenth century, and certainly not with great enthusiasm until the mid-twentieth century. This was when the university discovered its third idea, the idea that its primary purpose was to be useful. It was then that the sciences were harnessed to technology, and that social sciences emerged to demonstrate by analogy that the humanities should also be useful to society. Oakeshott was about as bleak about this as anyone has been. For him it was the "most momentous occurrence of this century, the greatest of the adversities to have overtaken our culture, the beginning of a dark age devoted to barbaric affluence." ${ }^{43}$

This brings us to the third idea of the university.

\section{The Immediate University}

Most critics before the mid-twentieth century argued that the immediate idea of the university was not an idea of the university at all. Clark Kerr, who coined the word "multiversity," used it to make it clear that there was no longer such a thing as a single idea of the university. Peter Scott declared in The Crisis of the University that the university was not "an organic academic society" but at most "a shared bureaucratic environment." 44 Shils called it "a site of conflict of fundamentally divergent interests." 45 Nonetheless, by exploring the postulates of what many of its critics claimed to be an anti-idea we can treat it as a recognisable idea in its own right.

The immediate university also has four characteristics. Firstly, it is concerned with knowledge for use. Secondly, the uses for which knowledge is available are not those of an elite, focused on truth or on a tradition of study, but on the needs of society as a whole, so this idea of the university is far closer to society than the other ideas. The telos of the university is to serve society: its ends should be decided by society, with the eventual result that the university should become identical with society: society as universitas. $^{46}$ If there is an elite it is solely an instrument. Thirdly, there is no merit in 
any truth or tradition except in so far as it serves some immediate purpose for society. As Clark Kerr wrote, "Instead of the distant past and the distant future, its attention is focused more and more on the current moment of time." ${ }^{\prime 47}$ Everything is available for use now: every resource can be exploited, including that of truth. Fourthly, since the needs of society are manifold, and the skills society needs in its many departments are diverse, the university involves a fundamental plurality of studies regulated only by administrative and commercial imperatives. This is because there is no one truth, and no one tradition: although there is one civilisation, it is a fact rather than something consciously to be preserved. There is no standard by which the university can conceptualise its own unity, except the abstract one of utility.

Historians remind us that all educational institutions, no matter how rarefied, have had a utilitarian aspect. Olaf Pedersen notes that in Egypt and Mesopotamia the first institutions of higher education were "schools for administrators." "They gave their pupils qualifications for power and influence in society." ${ }^{48}$ Gordon Leff notes that the medieval universities were "orientated towards this world." ${ }^{49}$ Pursuing a similar line of thought, the philosopher A. N. Whitehead wrote in the early twentieth century that "the novelty of business schools must not be exaggerated."

At no times have universities been restricted to pure abstract learning. The University of Salerno in Italy, the earliest of European universities, was devoted to medicine. In England, at Cambridge, in the year 1316, a college was founded for the special purpose of providing 'clerks for the King's service'. Universities have trained clergy, medical men, lawyers, engineers. Business is now a highly intellectualized vocation, so it well fits into the series.

He thought there was no reason why universities could not be extended to include business.

The universities have trained the intellectual pioneers of our civilisation-the priests, the lawyers, the statesmen, the doctors, the men of science, and the men of letters.... The conduct of business now requires intellectual imagination of the same type as that which in former times has mainly passed into those other occupations; and the universities are the organisations which have supplied this type of mentality for the service of the progress of the European races. ${ }^{50}$

It is difficult to find anyone apart from Whitehead in the literature about universities who has defended the immediate idea of the university. Most of what is written about it is negative, written by critics in order to defend the immortal university. ${ }^{51}$ So the only way to characterise it to attempt to turn what is said about it negatively into a positive account. An early critic was Nietzsche, who thought the university should not "subordinate itself to the service of the state, "for then "utility [would be] the object." He claimed that "only an exceedingly small number of people are destined for a true course of education, and that a much smaller number of higher educational establishments would suffice"; and he distinguished "two exact contraries: institutions for teaching culture and institutions for teaching how to succeed in life." ${ }^{52}$ Nietzsche was not at all sure whether philosophy would be possible within the university if it were constructed in terms of what I am calling the immediate idea. For T. S. Eliot such a thing meant the end of civilisation: "If we estimate the wisdom and experience and art of the past in terms of its usefulness to us, we are in danger of limiting the 
meaning of 'usefulness', and of limiting the meaning of 'us' to those of us who are now alive." 53

In the late 1960s Maurice Cowling adjusted the standard argument by proposing that the immortal university could only be defended if it were admitted that the immediate idea was an idea of the university. He advocated "two tiers for the universities." While Kingsley Amis had famously said that "more will mean worse," Cowling disagreed:

Now "more", whether or not it means worse, undoubtedly means something very different, and what I question is whether the sort of higher education that has been conducted in a comparatively small university community over the last fifty years should be made to be the staple for a large and expanding university population in the future. ${ }^{54}$

Cowling thought we should distinguish the "academic university" from the "nonacademic university." By "academic" he meant "where the connection between what a student studies and what he does afterwards is fortuitous-that is to say, it may be directly related or it may not, but that does not matter." Academic education was not suitable for everyone. On the other hand "national, practical or economic needs" required "an education designed for use." He admitted that "there is, and always has been, an overlap between the academic and non-academic function in existing universities," yet thought "use" and "fortuity" could be kept apart.

In the modern university, however, they have not been kept apart, because the immediate idea of the university has had an obvious appeal to both society and government. Clark Kerr in the Uses of the University (1963) came up with a series of metaphors for what I am calling the three ideas of the university. If the eternal university is a village with its priests, and the immortal university a town with its burgesses, then the immediate university is a city in which all are citizens, "a city of infinite variety." This was his "multiversity" - a term which has never caught on, though it is remembered. "The multiversity", he claimed, "is central to the further industrialization of the nation, to spectacular increases in productivity with affluence following, to the substantial extension of human life, and to worldwide military and scientific supremacy." Here we were in a world of slogans, but the following was realistic enough: "A life of affluence is replacing a philosophy of life as the main purpose of higher education." ${ }^{55}$ Sheldon Rothblatt was mordant about this: "The multiversity is the university of the Benthamites. Its utility it established on the basis of the calculus of pleasure, its capacity to satisfy the greatest number, to provide the greatest number of positional goods for the greatest number of people." ${ }^{56}$ Almost no one apart from politicians or adminstrators could recommend the immediate university as an ideal. But it has become the dominant idea in recent decades, if not for many academics, then certainly for those who feel responsible for justifying the expense of the universities to a taxed and represented populace.

According to the immediate idea, the university should be judged in terms of how far it serves the needs of society as a whole. In the words of the Robbins Report of 1963: "The Government has a responsibility to ensure that the development of higher education is adequate to national needs." ${ }^{57}$ We should no longer think of higher education as the provision of a public good, but as a means for the provision of public goods. Collini calls this "a redefinition of higher education." ${ }^{58} \mathrm{Now}$, it is important to recognise that the words "needs" or "goods" in such claims are ambiguous, and have been interpreted in 
two ways. The first is to say that the wealth of society should be maximised (this is usually a quantitative argument); and the second, not incompatible with the first but clearly separate from it, is to say that the wealth of society should be dispersed more fairly to all of its members (this is both a quantitative and a qualitative argument). Noel Annan emphasised the first: "One argument in favour of expansion carried all before it. This was the contention that higher education is the key to economic growth." ${ }^{59}$ The immediate university is in this respect the university by numbers. Almost every critic has found fault with the attempt to measure the success of universities by the standards of another society, the blunt response being that "society has successfully subdued large areas of the university," that the criterion is "effectiveness," and that the consequence is "intellectual chaos." ${ }^{60}$ A subtler analysis has revealed the emergence in the universities of an awkward corporate language that combines the dull tones of the bureaucrat and the bright tones of the economist. ${ }^{61}$ Administrators are now universally abused; and the chief reason is that they do not understand the university. ${ }^{62}$ But this particular objection is unfair. It would be better to say that they understand the university in terms of the immediate idea rather than the immortal idea usually favoured by academics themselves.

If critics on the right (for instance, Maskell and Robinson) have condemned the immediate university in its entirety, critics on the left (for instance, Collini) have found it harder to do so. Collini's critique of what is now happening to the universities depends on viewing them as "the only institutions where thinking is in principle not subordinate to any other purpose." ${ }^{63}$ This is clearly a restatement of the immortal idea. But his criticism is muted because he sympathises with the second way in which the immediate university may benefit society. In general, the staunchest critics of the immediate university have been those who have objected to both the university being used as an instrument to increase the wealth of society and the university being used as an instrument to improve society in other ways. The second way of interpreting the requirement that the university serve the needs of society is interesting because it seems to end in the identification of the university and society as a whole. But for the time being, until this identification is complete, the universities remain, as Shils put it, "instruments for the fulfillment of the ideal of social equality." ${ }^{64}$

The identification of the interests of the university and the interests of society has given the social sciences a particularly important place in the immediate university.

When the universities took the social sciences into themselves, they accepted a breach in the wall. As long as universities studied things remote in time and place, or timeless and spaceless things, they could maintain their freedom from the distraction of the contemporary and the near at hand. However, when they accepted as a legitimate academic subject the empirical description of the contemporary society, a close cognitive and moral interest in affairs outside the university was a breach in the separation of the university from its environing society. ${ }^{65}$

Formally considered, the immediate university has no hierarchy of subjects. "All university degrees are of equal status." ${ }^{\prime 66}$ But since the criterion is utility, we may say that in the immediate university there is a de facto hierarchy, as is evident in some of the new universities. Here the first tier subjects are vocational (engineering, medicine, law, 
theology, business and management), followed by the natural sciences, especially those with obvious benefits to society, then the social sciences (whose efficacy is yet to be demonstrated but whose inclusion is close to being an ideological necessity), with the humanities coming last. The displacement of the humanities surely explains why so much of the literature about the state of the university has been written by humanists.

The immediate university is "to a great extent the creation of the state." ${ }^{67}$ The state either pays for it, or decides who shall pay for it. Shils notes that in 1900 the "universities had rather clearly demarcated boundaries separating them from the rest of the societies in which they lived." ${ }^{68}$ That this is no longer the case is a sign of how important the immediate idea has become in our time. The purpose of this university is-in Heidegger's words - "to help carry the burden of and to participate actively in the struggles, striving and skills of all the estates and members of the people." ${ }^{\text {"69 }}$ (Bloom scoffed: "The university may have come near its death when Heidegger put philosophy at the service of German culture. ${ }^{170}$ ) But even Heidegger could not have anticipated that universities would come to resemble "think-tanks, performing art complexes, and apprentice-programmes, as well as... sports clubs, community centres, and dating agencies." 71 Or that the university would have to trade in "the multitude of offhand sayings, flippant judgements, and shallow generalisations, with which the world abounds", ${ }^{72}$ that it would express its own purposes in a language which combines "windy assertiveness with banality,"73 or that it would offer "courses in which the products of pop culture are granted parity with (or even precedence over) the most important cultural achievements of our civilisation." ${ }^{74}$

\section{Conclusion}

The present essay is indebted to all of the writers it has quoted. It does not advocate one unitary idea of the university: it does not claim that this is a university, whereas that or the other is not a university. Rather than proposing a stipulative or singular definition of the university, as if laying down a standard that actual institutions will probably somehow fail to meet, this essay has defined the university capaciously, by laying down several rival sets of standards. The argument is that the university, as we understand it today, is, in fact, an actuality that derives from or is dependent on three rival ideas.

The argument is original, and, as far as it can be, philosophical. Here the philosophy is not an abstract beginning from first principles-if first principles in a subject like this were even possible-but is on the one hand an ordering of our experience of the university at present and a drawing out of intimations evident in history of what the university has been at various times and must still be if it maintains some continuity with its past, on the other. This is also what I believe philosophy should be: an exercise in what we should still call the philosophy of history.

I have not characterised the university in the abstract in terms of its activities (the standard list of "teaching, research, public service and learning"), ${ }^{75}$ nor have I characterised its history in terms of a shift from one idea to another. I would not want to obscure the fact that actual universities have served many purposes. As Lawrence Stone reminds us, "The ostensible functions of a university often conceal 
equally or more important latent ones (the most critical of which is keeping adolescents out of trouble)." ${ }^{76}$ But I have argued that no matter what is going on in fact, there are three ideas that have always been intimated in the history of higher education, which have been established theoretically at various points in history, and which, as ideas, are more or less coherent, even though one of them, the last-the immediate idea of the university - is usually taken by its critics to be incoherent.

None of the ideas I describe has ever existed in pure form. There has never been a purely eternal university, any more than there has ever been a purely immortal or purely immediate university. These are three ideas which, at various times, have been glimpsed, sometimes securely, sometimes less securely, and which, at various times, have been supposed by some to be the idea in terms of which the actual university should be understood. Historically considered, we are in an age in which the third idea has come to challenge the previously hegemonic second idea, and in which this struggle between the two ideas sometimes means that the first idea is forgotten, though much of the prestige of the institution of the university derives from it.

We often hear about the decline of the university. But we must be wary of the temptation to write in terms of decline, since often what is supposed to be a decline within one arc of time is simply an abstraction from a far more complicated history. Collini suggests that the university can be considered "something of a palimpsest of successive social and educational ideals." 77 But it seems to me that all three ideas survive, and jostle together, in the university, and in what we write about it. Far from claiming that there has been a decline (though I have no doubt that there are many obvious contemporary or practical reasons for thinking there has been), I would claim that these three ideas have always been intimated in all institutions of higher education that have ever existed and, though these ideas were clarified at different times, they continue in a more or less clear form today. The corollary of this is that any actual university can be judged in terms of these three distinct ideas.

No single idea can express everything that universities have been. Perhaps the only way to formulate a pure theory of the university would be to embrace a paradox. A. H. Halsey threw out a brilliant reductio ad absurdum along these lines: "In the most general terms the university is the realisation of a single idea-the idea of a social institution to ensure the continuity of intellectual constructions. But thought is incorporated into all institutions. Hence the university is in principle substitutable. It has a monopoly of nothing." ${ }^{78}$ Voila! But there is no need to be as paradoxical as this. Instead of beginning with the obsolete idea that there is one idea of the university, or the conventional view that there are two ideas, I have argued that we should begin by accepting that there are three ideas. Certainly, if we saw the university in this way we would be able to restore some of the philosophical spirit and sense of proportion that have for some time been lacking in polemical writing about it.

\section{Notes}

1. Coleridge, Constitution of Church and State, 4.

2. Hofstetter, Romantic Idea of a University, $\mathrm{x}$.

3. Rothblatt, "Idea of the Idea of a University," 1. Philosophers, though perhaps not historians, will know that the two uses of "idea" in his title refer to two completely different things. 
4. Humboldt's idea of the university is still used by some (e.g., Habermas) as formative, but it tends to encourage the typical bipolarity-favoured by humanists but also evident in the writings of poststructuralists like Lyotard-whereby what I am calling the immortal idea of the university is opposed to the immediate idea. Newman and Humboldt both looked backwards to the medieval university: but Humboldt's Bildung stripped religion out of the university, because his preoccupations were with natural rather than with revealed religion, and thus were more easily secularised into a "human vocation." Scholars who begin with Humboldt tend to treat his idea of the university as an absolute origin and blueprint rather than as an ambiguous continuation of a longer history. See, for instance, Kwiek, "Revisiting the Classical German Idea."

5. Compare Newman, Discourses on the Scope and Nature of University Education and Newman, Idea of a University. I shall quote from the former.

6. See, for instance, Jaspers, Idea of the University; Leavis, "Idea of a University"; Oakeshott, "Idea of a University" (in Voice of Liberal Learning, 95-104); Minogue, Concept of a University; Cameron, Idea of a University; Halsey, "The Idea of a University"; Habermas, "Idea of the University"; Pelikan, Idea of the University; Maskell and Robinson, New Idea of the University; and Scruton, "Idea of the University." These are only the most renowned works or the ones I have found most useful. Any check of a library catalogue will reveal many other works.

7. Chadwick, Spirit of the Oxford Movement, 100. Humboldt was sometimes no better: "Humboldt abided by the first two commandments for any great writer: (1) Thou shalt be vague, (2) Thou shalt not eschew self-contradiction." Deutscher, Through the Language Glass, 136.

8. Dunne, "Newman Now," 412.

9. Maskell and Robinson, New Idea of the University, 28.

10. Ibid., 29.

11. Newman, Discourses, 187, 188, 196, 340.

12. Leavis, "Idea of a University"; Oakeshott, Voice of Liberal Learning; Bloom, Closing of the American Mind; Ginsberg, Fall of the Faculty; Nussbaum, Cultivating Humanity; Collini, Speaking of Universities.

13. Maclntyre, God, Philosophy, Universities; Higton, Theology of Higher Education.

14. Beckwith, Warriors of the Cloisters.

15. Makdisi, Rise of Colleges, 281.

16. Leff, Paris and Oxford, 3, 5.

17. Weil, Gravity and Grace, 56.

18. Berkey, Transmission of Knowledge, 5 .

19. Minogue, Concept of a University, 17, 39, 47.

20. Lyons, "Idea of a University," 114.

21. Newman, Discourses, 381.

22. G. K. Chesterton quoted in Clark, God, Religion and Reality, 43. Clark observes that Heidegger also related thinking and thanking (see 163).

23. MacIntyre, God, Philosophy, Universities, 146, 152-53, 173-74, 179.

24. Robert Maynard Hutchins quoted in Gray, Searching for Utopia, 11-12.

25. Leavis, "Idea of a University," 19.

26. Brunner, Christianity and Civilisation, vol. 1, 75; ibid., vol. 2, 46.

27. Minogue, Concept of a University, 65.

28. Grafton and Jardine, From the Humanists to the Humanities, xv.

29. Annan, Our Age, 534.

30. Oakeshott, Voice of Liberal Learning, 111, 114, 129, 130, 103.

31. Collini, What Are Universities For?, 149.

32. Leavis, Nor Shall My Sword, 27, 183, 207.

33. Oakeshott, "Study of Politics," 188, 187.

34. Leavis, "Idea of a University," 24, 25 and 31.

35. Oakeshott, Voice of Liberal Learning, 30.

36. Leavis, Nor Shall My Sword, 158. 
37. Bloom, Closing of the American Mind, 38.

38. Minogue, Concept of a University, 60.

39. Shils, Order of Learning, 66.

40. Bloom, Closing of the American Mind, 254 and 272.

41. Leavis, "Idea of a University," 15; Leavis, English Literature in Our Time, 30.

42. Newman, Discourses, 70-72.

43. Oakeshott, Voice of Liberal Learning, 90.

44. Quoted in Halsey, "Idea of a University," 117.

45. Shils, Order of Learning, 63.

46. For a theory of universitas along these lines, see Oakeshott, On Human Conduct.

47. Quoted in Schrum, "To 'Administer the Present'," 510.

48. Pedersen, The First Universities, 3-4.

49. Leff, Paris and Oxford, 2.

50. Whitehead, "Universities and their Function," 92, 95.

51. I leave to one side the literature on the "postmodern university" since I consider that this literature consists of nothing more than attempts to solve a riddle by repeatedly restating it. It bears all the marks of wanting to offer a critique while taking away its own capacity to offer one. For more on this, see Donovan, "Beyond the 'Postmodern University'."

52. Nietzsche, Our Educational Institutions, 12-13, 73 and 98.

53. Eliot, "Aims of Education," 119.

54. Cowling, "Two Tiers for the Universities," 716-17.

55. Kerr, Uses of the University, 199, 221.

56. Rothblatt, "Idea of the Idea of a University," 21.

57. [Robbins], Higher Education Report, 228.

58. Collini, What Are Universities For?, 178-79.

59. Annan, Our Age, 502.

60. Minogue, Concept of a University, 82-83.

61. Prickett, "Conclusion," in Prickett and Erskine-Hill, Education! Education! Education!, 185. For mockery of this language, see Maskell and Robinson, New Idea of the University, 3.

62. Administrators don't know what a university "is or ought to be." Wilshire, Moral Collapse of the University, 83. "Controlled by administrators... the university can never be more than... a knowledge factory, offering more or less sophisticated forms of vocational training to meet the needs of other established institutions in the public and private sectors." Ginsberg, Fall of the Faculty, 3.

63. Collini, Speaking of Universities, 25.

64. Shils, Order of Learning, 55.

65. Ibid., 60.

66. Ibid., 79.

67. Scruton, "Idea of a University," 81.

68. Shils, Order of Learning, 40.

69. Heidegger, "Self-Assertion of the German University," 10.

70. Bloom, Closing of the American Mind, 311.

71. Collini, What Are Universities For?, 12.

72. Newman, Discourses, 108.

73. Maskell and Robinson, New Idea of the University, 67.

74. Kimball, Tenured Radicals, xii-iii.

75. Fincher, "Idea of the University," 28.

76. In Phillipson, ed., Universities, Society, and the Future, 28.

77. Collini, What Are Universities For?, 154.

78. Halsey, "Idea of a University," 130. 


\section{Disclosure Statement}

No potential conflict of interest was reported by the author(s).

\section{Notes on contributor}

James Alexander originally studied history at Cambridge University, England, and now teaches politics in Bilkent University, Ankara, Turkey. He is the author of articles on history, ideology, tradition and politics, including "The Fundamental Contradiction of Cosmopolitanism" (The European Legacy, 2015).

\section{Bibliography}

Annan, Noel. The Dons: Mentors, Eccentrics, Geniuses. Chicago, IL: University of Chicago Press, 1999. Annan, Noel. Our Age: The Generation That Made Post-War Britain. London: Fontana, 1991.

Beckwith, Christopher, Warriors of the Cloisters: The Central Asian Origins of Science in the Medieval World. Princeton, NJ: Princeton University Press, 2012.

Berkey, J. P. The Transmission of Knowledge in Medieval Cairo: A Social History of Islamic Education. Princeton, NJ: Princeton University Press, 1992.

Bloom, Allan. The Closing of the American Mind. New York: Simon \& Schuster, 1987.

Brunner, Emil. Christianity and Civilisation. 2 vols. London: Nisbet \& Co., 1949.

Cameron, James Munro. On the Idea of a University. Toronto: University of Toronto Press, 1978.

Chadwick, Owen. The Spirit of the Oxford Movement: Tractarian Essays. Cambridge: Cambridge University Press, 1990.

Clark, Stephen. God, Religion and Reality. London: S.P.C.K., 1998.

Coleridge, Samuel Taylor. On the Constitution of Church and State According to the Idea of Each. 1830. Edited by John Barrell. London: J. M. Dent, 1972.

Collini, Stefan. Speaking of Universities. London: Verso, 2017.

Collini, Stefan. What Are Universities For? London: Penguin, 2012.

Cowling, Maurice. "Two Tiers for the Universities." Spectator, May 30, 1969, 716-17.

Deutscher, Guy. Through the Language Glass: Why the World Looks Different in Other Languages. New York: Metropolitan Books, 2010.

Donovan, Claire. "Beyond the 'Postmodern University'." The European Legacy 18 (2013): 242-41.

Dunne, Joseph. "Newman Now: Re-Examining the Concepts of 'Philosophical' and 'Liberal' in 'The Idea of a University'." British Journal of Educational Studies 54 (2006): 412- 28.

Eliot, T. S. "The Aims of Education." In To Criticise the Critic. London: Faber \& Faber, 1965.

Fincher, Cameron, "The Idea of the University in the 21st Century: An American Perspective." British Journal of Education Studies 41 (1993): 26-45.

Ginsberg, Benjamin. The Fall of the Faculty: The Rise of the All-Administrative University and Why It Matters. Oxford: Oxford University Press, 2011.

Grafton, Anthony, and Lisa Jardine. From the Humanists to the Humanities: Education and the Liberal Arts in Fifteenth and Sixteenth-Century Europe. Cambridge, MA: Harvard University Press, 1986.

Gray, Hanna Holborn. Searching for Utopia: Universities and their Histories. Berkeley: University of California Press, 2012.

Habermas, Jürgen. "The Idea of the University: Learning Processes." New German Critique 41 (1987): 3-22.

Halsey, A. H. "The Idea of a University: The Charles Carter Lecture." Oxford Review of Education 11 (1985): 115-13.

Heidegger, Martin. "The Self-Assertion of the German University." 1933. In Martin Heidegger and National Socialism, edited by Günther Neske and Emil Kettering, 5-14. New York: Paragon House, 1990. 
Higton, Mike. A Theology of Higher Education. Oxford: Oxford University Press, 2012.

Hofstetter, Michael J. The Romantic Idea of a University: English and German Universities, 1770-1850. London: Palgrave, 2001.

Jaspers, Karl. The Idea of the University. 1923; 1946. Translated by H. A. T. Reiche and H. F. Vanderschmidt. Edited by Karl W. Deutsch. London: Owen, 1960.

Kerr, Clark. The Uses of the University. 5th ed. Cambridge, MA: Harvard University Press, 2001.

Kimball, Roger. Tenured Radicals: How Politics has Corrupted Our Higher Education. New York: Harper \& Row, 1990.

Kwiek, Marek. "Revisiting the Classical German Idea of the University (On the Nationalisation of the Modern Institution)." Polish Journal of Philosophy 2 (2008): 1-25.

Leavis, F.R. English Literature in Our Time and The University: The Clark Lectures 1967. London: Chatto \& Windus, 1969.

Leavis, F. R. "The Idea of a University." In Education and the University: A Sketch for an "English School. " 2d ed. London: Chatto \& Windus, 1948.

Leavis, F. R. Nor Shall My Sword: Discourses on Pluralism, Compassion and Social Hope. London: Chatto \& Windus, 1972.

Leff, Gordon. Paris and Oxford in the Thirteenth and Fourteen Centuries: An Institutional and Intellectual History. New York: John Wiley, 1968.

Lyons, F. S. L. "The Idea of a University: Newman to Robbins." In Universities, Society, and the Future, edited by Nicholas Phillipson, 113-44. Edinburgh: Edinburgh University Press, 1983.

Maclntyre, Alasdair. God, Philosophy, Universities: A Selective History of the Catholic Philosophical Tradition. London: Continuum, 2009.

Makdisi, George. The Rise of Colleges: Institutes of Learning in Islam and the West. Edinburgh: Edinburgh University Press, 1981.

Maskell, Duke, and lan Robinson. The New Idea of the University. London: Haven, 2001.

Minogue, Kenneth. The Concept of a University. London: Weidenfeld \& Nicolson, 1973.

Newman, John Henry. Discourses on the Scope and Nature of University Education. Dublin: James Duffy, 1852.

Newman, John Henry. The Idea of a University Defined and Illustrated. 1852. London: Longmans, Green \& Co., 1912.

Nietzsche, Friedrich. On the Future of Our Educational Institutions. Translated by J. M. Kennedy. London: T.N. Foulis, 1910.

Nussbaum, Martha. Cultivating Humanity: A Classical Defense of Reform in Liberal Education. Cambridge, MA: Harvard University Press, 2013.

Oakeshott, Michael. On Human Conduct. Oxford: Clarendon Press, 1975.

Oakeshott, Michael. "The Study of Politics at a University." In Rationalism in Politics and Other Essays, edited by Timothy Fuller, 184-218. Indianapolis: Liberty Fund, 1991.

Oakeshott, Michael. The Voice of Liberal Learning: Michael Oakeshott on Education, edited by Timothy Fuller. New Haven, CT: Yale University Press, 1989.

Pedersen, Olaf. The First Universities: Studium Generale and the Origins of University Education in Europe. Translated by Richard North. Cambridge: Cambridge University Press, 1997.

Pelikan, Jaroslav. The Idea of the University: A Re-examination. New Haven, CT: Yale University Press, 1992.

Phillipson, Nicholas, ed. Universities, Society, and the Future. Edinburgh, Edinburgh University Press, 1983.

Prickett, Stephen, and Patricia Erskine-Hill, eds. Education! Education! Education!: Managerial Ethics and the Law of Unintended Consequences. Exeter, UK: Imprint Academic, 2002.

[Robbins]. Higher Education Report of the Committee Appointed by the Prime Minister under the Chairmanship of Lord Robbins 1961-63. London: Her Majesty's Stationery Office, 1963.

Rothblatt, Sheldon. "The Idea of the Idea of a University and Its Antithesis." In The Modern University and Its Discontents: The Fate of Newman's Legacies in Britain and America. Cambridge: Cambridge University Press, 1997.

Schrum, Ethan. "To 'Administer the Present': Clark Kerr and the Purpose of the Postwar American Research University." Social Science History 36 (2012): 499-523. 
Scruton, Roger. "The Idea of the University." In Prickett and Erskine-Hill, Education! Education! Education!.

Shils, Edward. The Order of Learning: Essays on the Contemporary University. London: Transaction Publishers, 1997.

Weil, Simone. Gravity and Grace. 1947. London: Routledge, 2002.

Whitehead, Alfred North. "Universities and their Function." In The Aims of Education and Other Essays. 1929. London: Macmillan, 1957.

Wilshire, Bruce. The Moral Collapse of the University: Professionalism, Purity and Alienation. Albany: State University of New York Press, 1990. 